\title{
Strategi Politik Luar Negeri Indonesia dalam Upaya Mitigasi Pandemi Global COVID-19
}

\author{
Hanifahturahmi \\ STISIP Persada Bunda \\ Email: hanifahturahmi20@gmail.com
}

\begin{abstract}
Abstrak
Penelitian ini bertujuan untuk menganalisis strategi politik luar negeri Indonesia dalam upaya mitigasi pandemi global COVID-19 dan faktor-faktor yang mempengaruhi strategi politik luar negeri Indonesia tersebut. Penelitian ini menggunakan perspektif behavioralisme dengan level analisa negara bangsa. Adapun metode yang digunakan dalam penelitian ini adalah metode penelitian kualitatif. Hasil penelitian menunjukkan bahwa strategi politik politik luar negeri Indonesia dalam upaya mitigasi pandemi global COVID-19 adalah melalui Alliance for Multilateralism yang fokus pada dua hal. Pertama, pemerintah Indonesia berupaya untuk memberikan perlindungan terhadap WNI di luar negeri. Kedua, pemerintah Indonesia medorong penguatan tata kekola dalam kerangkan global health dengan cara mendukung kebijakan yang dikeluarkan oleh WHO dan menjalin kerjasama baik, regional maupun multilateral. Faktor-faktor yang mempengaruhi strategi politik politik luar negeri Indonesia dalam upaya memitigasi pandemi global COVID-19 adalah kepentingan nasional Indonesia dan konstelasi politik internasional. Kepentingan nasional Indonesia fokus pada upaya perlindungan terhadap warga negara Indonesia baik yang ada di dalam negeri maupun yang ada di luar negeri. Sementara itu konstelasi politik internasional menjadi semakin konfliktual karena rasa saling curiga antara negara-negara maju yang terlibat persaingan dagang dalam bidang industri kesehatan.
\end{abstract}

Kata Kunci: Politik luar negeri, COVID-19, pandemi global, mitigasi

\section{Abstract}

This research aims to analyze Indonesia's foreign policy strategy to mitigate the global COVID19 pandemic and the factors that affect Indonesia's foreign policy strategy. This research uses the perspective of behavioralism with the level of nation-state analysis. The method used in this research is qualitative research methods. The results show that Indonesia's foreign policy strategy in mitigating the global COVID-19 pandemic is through Alliance for Multilateralism that focuses on two things. First, the Indonesian government seeks to protect Indonesian citizens abroad. Second, the Indonesian government encourages strengthening governance within the framework of global health by supporting policies issued by WHO and establishing good cooperation, regionally and multilaterally. The factors that influence Indonesia's foreign policy strategy in efforts to mitigate the global COVID-19 pandemic are Indonesia's national interests and the international political constellation. Indonesia's national interests focus on protecting Indonesian citizens both at home and abroad. Meanwhile, the international political constellation has increased conflicts due to mutual suspicion between developed countries that are involved in trade competition in the health industry.

Keywords: Foreign policy, COVID-19, global pandemic, mitigation

DOI: $10.36341 /$ jdp.v4i2.1916 


\section{PENDAHULUAN}

Pandemi global yang terjadi saat ini disebabkan oleh virus corona jenis baru. Pandemi tidak hanya menyangkut permasalahan krisis kesehatan suatu negara melainkan krisis kesehatan global yang berdampak pada kondisi sosial dan ekonomi negara-negara yang terkena dampaknya. Sikap tenang pemerintah Indonesia yang ditunjukkan terhadap pendemi ini berubah ketika terjadi tingginya angka kematian di beberapa negara seperti Amerika Serikat dan Italia.

Lemahnya keamanan antar negara serta deteksi dini berdampak pada meningkatnya penyebaran virus corona secara masif. Dengan demikian keamanan manusia (human security) menjadi terancam karena fenomena trans-nasionalisasi virus tersebut. Dengan kondisi tersebut negara-negara di dunia dituntut untuk menyesuaikan diri dengan dinamika baru yang telah berubah. Pandemi global yang disebabkan oleh penyebaran COVID-19 bahkan mengacam perdamaian dan keamanan internasional karena menimbulkan kecurigaan di berbagai negara terkait asal usul virus.

Banyak aktor internasional yang mengaitkan asal usul kemunculan virus Corona dengan kepentingan negara-negara tertentu, karena penularan virus yang menyebabkan terjadinya pandemi global bukanlah kasus krisis kesehatan global pertama di dunia. Pada masa Perang Dunia I ketika terjadi persaingan antara Blok Sekutu dan Blok Sentral, dunia juga mengalami wabah flu Spanyol pada awal tahun 1918. Kemudian pada masa Perang Dingin ketika terjadi persaingan geopolitik antara Uni Soviet dan Amerika Serikat, dunia juga menghadapi wabah smallpox. Aspek keamanan yang sebelumnya terfokus pada kemananan nasional bergeser menjadi keamanan manusia (human security) yang sebelumnya bukanlah prioritas negara pada masa itu. Sementara itu, sejak penularan COVID-19 mulai mewabah hingga saat ini semakin menunjukkan persaingan geopolitik antara Amerika Serikat dan Tiongkok. Kedua negara saling melakukan propaganda mengenai asal usul virus hingga wacana penarikan diri Amerika Serikat dari keanggotaan WHO karena menganggap WHO dikuasai oleh Tiongkok (Akhli 2020).

Berdasarkan krisis kesehatan global yang pernah terjadi sebelumnya hingga pandemi global akibat COVID-19 ini, tidak menutup kemungkinan terjadi pergeseran politik internasional dan strategi politik luar negeri suatu negara, termasuk Indonesia. Pandemi global COVID-19 sangat berdampak besar terhadap kondisi sosial, ekonomi, politik dan keamanan nasional, sehingga memerlukan penanganan secara komprehensif. Secara internal perlu adanya kerjasama dari kelompok masyarakat sipil dan pemerintahan disertai kepemimpinan yang responsif di semua level disamping menjaga kepercayaan publik dengan sikap yang transparan, penguatan fungsi komunikasi yang lebih humanis dan empatik. Sementara itu secara eksternal diperlukan kebijakan luar negeri yang tepat dari berbagai negara mengingat dampak yang meluas akibat adanya pandemi global ini terhadap konstelasi politik internasional.

Berbagai negara telah melakukan upaya terhadap penanganan pandemi global COVID-19, seperti Amerika Serikat dan Republik Rakyat Tiongkok. Melalui Departemen Luar Negeri AS dan USAID, AS telah mengeluarkan Lebih dari 490 juta dolar AS dalam bentuk bantuan kesehatan darurat dari Dana Cadangan Darurat Kesehatan Global USAID untuk pos pendanaan Wabah Penyakit Menular dan Program Kesehatan Global (U.S. Embassy Jakarta 2020). Sementara itu Tiongkok memberikan bantuan kepada WHO sebesar 30 juta dolar Amerika (Financial Times 2020). 
Sebagai bentuk solidaritas kemanusiaan, Indonesia juga melakukan berbagai upaya untuk menyelesaikan berbagai dampak yang ditimbulkan oleh pandemi global ini. Indonesia aktif melakukan engangemet dengan tujuan untuk melakukan kerjasama internasional dalam penanganan COVID-19. Upaya ini tentunya tidak terlepas dari strategi politik luar negeri Indonesia dalam mempertahankan kepentingan nasionalnya di dalam konteks global yang berubah karena adanya pandemi global yang telah berdampak pada kondisi sosial, politik dan keamanan nasional di Indonesia. Penelitian ini akan membahas strategi politk luar negeri Indonesia yang harus bersifat proaktif dan adaptif terhadap keterkaitan berbagai persoalan yang telah ditimbulkan oleh pandemi COVID-19 serta faktor-faktor yang mempengaruhi strategi politik luar negeri Indonesia dalam mitigasi pandemi COVID-19 sehingga hubungan luar negeri yang terjalin lebih sehat dan dinamis.

\section{POLITIK LUAR NEGERI INDONESIA}

Berdasarkan Undang-Undang tentang Hubungan Luar Negeri No. 37 Tahun 1999 Pasal 1 Ayat 2, politik luar negeri Indonesia adalah: "kebijakan, sikap, dan langkah Pemerintahan Republik Indonesia yang diambil dalam melakukan hubungan dengan negara lain, organisasi internasional, dan subyek hukum internasional lainnya dalam rangka menghadapi masalah internasional guna mencapai tujuan nasional". Politik luar negeri juga dapat didefinisikan sebagai serangkaian kebijakan pemerintah dalam rangka hubungannya dengan dunia internasional untuk mencapai tujuan nasional, dimana pemerintah memproyeksikan kepentingan nasional ke dalam masyarakat antar bangsa (Sabir 1987).

Rosenau, mengatakan bahwa politik luar negeri suatu negara pada hakekatnya merupakan suatu mekanisme untuk negara-bangsa menyesuaikan diri dengan berbagai perubahan di lingkungannya (Perwinta and Yani 2005). Walaupun politik luar negeri Indonesia tetap pada prinsip "Bebas-Aktif", instrumen politik luar negeri Indonesia akan berubah seiring dengan perkembangan lingkungan baik internal maupun eksternal. Perubahan juga akan dipengaruhi dengan adanya perubahan rezim pemerintahan yang ditandai dengan kepemimpinan nasional baru sebagai bentuk produk dari demokrasi yang telah berjalan. Indonesia bahkan lebih percaya diri dalam pelaksanaan diplomasi dan politik luar negeri serta memainkan peran yang lebih aktif lagi ditingkat regional maupun global (Perwinta 2007).

Definisi politik luar negeri di atas sejalan dengan istilah yang dikeluarkan oleh Henry Kissinger, "foreign policy begins when domestic policy ends" (Hanrieder, Wolfram 1971). Artinya politik luar negeri tidak hanya memandang aspek eksternal (internasional) akan tetapi juga didasarkan pada aspek internal (dalam negeri) suatu negara. Dengan demikian politik luar negeri erat kaitannya dengan national interest (kepentingan nasional) suatu negara. Ketika masing-masing negara memiliki kepentingan nasional yang berbeda, maka rumusan politik luar negeri masing-masing negara tentunya juga akan berbeda.

Menurut Hans. J Morghentau, kepentingan nasional merupakan pilar utama untuk mendukung politik luar negeri dan politik internasional suatu negara (Mas'oed 1990). Sementara itu konsep kepentingan nasional menurut Jack C. Plano dan Roy Olton adalah tujuan mendasar serta faktor yang menetukan dan memandu para 
pembuat keputusan dalam merumuskan politik luar negeri (Plano and Olton 1982). Artinya, kepentingan nasional ini sangat penting dalam menjelaskan dan memahami perilaku negara dalam sistem internasional yang dapat dijelaskan sebagai tujuan fundamental dan faktor penentu akhir yang mengarahkan para pembuat keputusan dari suatu negara dalam merumuskan kebijakan luar negerinya.

Sejak WHO menetapkan COVID-19 sebagai pandemi, berbagai negara mulai menerapkan berbagai kebijakan guna menghentikan penyebaran virus sekaligus mempertahankan keamanan nasionalnya. Keamanan nasional yang dimaksud saat ini bukan lagi disebabkan karena ancaman militer ataupun terorisme melainkan ancaman terhadap keamanan manusia (human security). Untuk itu pemerintah Indonesia melakukan berbagai upaya untuk melindungi warga negaranya baik di dalam negeri maupun yang berada di luar negeri, salah satunya melalui upaya diplomasi perlindungan (diplomatic protection) bagi WNI yang terkena dampak dari pandemi.

Diplomasi merupakan suatu proses interaktif dua negara atau lebih melalui perwakilan resmi guna mencapai politik luar negeri negara yang terlibat dalam proses tersebut. Proses interaktif dua negara atau lebih yang bertujuan untuk memberikan perlindungan bagi warga negaranya yang berada di luar negeri disebut dengan diplomasi perlindungan. Perlindungan negara bagi warga negara merupakan salah satu hak warga negara seperti penjelasan yang tertuang di dalam Batang Tubuh UUD 1945 Pasal 28 D Ayat 1, bahwa "Setiap orang berhak atas pengakuan, jaminan, perlindungan, dan kepastian hukum yang adil serta perlakuan yang sama di hadapan hukum". Dengan demikian melalui diplomasi perlindungan, negara berupaya untuk memenuhi hak asasi manusia warga negaranya. Salah satu bentuk perlindungan terhadap warga negara Indonesia adalah melalui bantuan dan perlindungan kekonsuleran yang diberikan oleh perwakilan resmi negara dalam kerangka pelayanan warga seperti yang di atur dalam Peraturan Menteri Luar negeri Republik Indonesia No. 4 Tahun 2008 tentang Pelayanan Warga pada Perwakilan Republik Indonesia di Luar Negeri.

\section{Alliance for Multilateralism}

Alliance for Multilateralism merupakan suatu jaringan informal beberapa negara dengan menyatukan keyakinannya bahwa tatanan multilateral berbasis aturan adalah satusatunya yang dapat menjamin stabilitas dan perdamaian internasional dan bahwa tantangan internasional hanya dapat diselesaikan melalui kerjasama. Aliansi bertujuan untuk memperbarui komitmen negara-negara di dunia untuk menjaga stabilitas tatanan internasional yang berbasis aturan, menjunjung tinggi prinsip-prinsip internasional dan bila perlu negara-negara dapat menyesuaikan diri dengan kondisi yang ada. Hal ini juga bertujuan untuk melindungi dan melestarikan norma-norma internasional, perjanjian internasional, dan lembaga-lembaga yang berada dibawah tekanan atau dalam bahaya, guna menghasilkan agenda yang lebih proaktif dalam kebijakan yang tidak memiliki tata kelola yang efektif dan dimana munculnya tantangan baru yang memerlukan tindakan kolektif dan reformasi tanpa mengabaikan priinsip-prinsip dan nilai utama, agar lembaga-lembaga multilateral dan tatanan ekonomi dan politik global lebih inklusif dan efektif bagi seluruh masyarakat internasional (Alliance for Multilateralism n.d.).

Aliansi mendukung tatanan multilateral yang univerasal dan efektif. Aliansi terbuka untuk setiap negara yang berkomitmen untuk berkontribusi pada tatanan 
internasional berbasis aturan dan kerjasama multilateral, berdasarkan aturan hukum yang tertuang dalam Piagam PBB dan hukum internasional. Multilateralisme dalam konteks kebijakan luar negeri artinya negara-negara bekerjasama satu sama lain untuk mempromosikan tujuan bersama dan menyeimbangkan serta mengatur kepentingan yang bersaing dengan pendekatan bahwa pada akhirnya semua negara menuai keuntungan terbesar jika mereka bekerjasama dan mengikuti aturan (Alliance for Multilateralism n.d.).

Negara sebagai decision maker merupakan aktor rasional. Dalam merumuskan kebijakan luar negerinya, negara akan mempertimbangkan berbagai pilihan rasional dan konsekuensinya. Melalui Alliance for Multilateralism, negara akan memilih alternatif kebijakan yang memiliki konsekuensi paling tinggi (menguntungkan) dalam memenuhi tujuan yang ingin dicapai (goals and objectives) tanpa mengabaikan norma-norma internasional.

\section{METODE PENELITIAN}

Penelitian ini menggunakan metode penelitian kualitatif (qualitative research) dengan pendekatan analisis deskriptif agar mudah dipahami oleh pembaca. Metode ini dibantu dengan pengoperasian konsep-konsep dan teori yang relevan. Adapun data yang digunakan dalam penelitian ini merupakan data sekunder yang dikumpulkan dari berbagai sumber melalui studi literature (kepustakaan). Teknik analisa data dalam penelitian ini menggunakan model analisis interaktif yang dikemukakan oleh Miles dan Huberman. Model analisis interaktif terdiri dari beberapa kegiatan, mulai dari pengumpulan data, reduksi data, penyajian (display) data, dan verifikasi atau penarikan kesimpulan (Sugiyono 2012).

\section{PEMBAHASAN}

\section{Dampak Penyebaran COVID-19 bagi Indonesia}

COVID-19 yang awalnya merupakan kasus pneumonia di Wuhan telah ditetapkan sebagai pandemi global oleh WHO. Hal ini dikarenakan COVID-19 telah menyebar dengan cepat ke berbagai negara di dunia, sehingga jumlah pasien yang dinyatakan positif COVID-19 semakin meningkat setiap harinya. Pandemi COVID-19 bukan hanya sekedar permasalahan krisis kesehatan, akan tetapi merupakan permasalah keamanan manusia karena telah menyebabkan tingginya angka kematian, mengancam kesehatan, lingkungan sosial dan perekonomian di berbagai negara.

Indonesia mengumumkan kasus positif pertama pada tanggal 2 Maret 2020. Kemudian pada tanggal 13 April 2020, pemerintah Indonesia menyatakan bahwa COVID-19 sebagai bencana non alam nasional. Pemerintah Indonesia menerapkan pembatasan sosial skala besar (PSBB) di berbagai kota-kota besar di Indonesia, sehingga mempengaruhi kegiatan sosial dan ekonomi masyarakat. Pada 6 Juni 2020, pemerintah Indonesia telah mengkonfirmasi sebanyak 30.514 kasus COVID-19 di seluruh 34 provinsi dengan total kematian yang dilaporkan sebanyaj 1.801 jiwa (OCHA and CRO 2020).

Banyak dampak yang ditimbulkan dari adanya penyebaran COVID-19 bagi Indonesia terutama dengan dikeluarkannya kebijakan protokol kesehatan COVID-19. 
Kebijakan protokol Kesehatan merupakan upaya pemerintah Indonesia untuk memutus rantai penyebaran COVID-19 dan mengurangi jumlah warga yang positif COVID-19. Namun kebijakan ini tentunya juga harus didukung oleh kesadaran, kedisiplinan serta pasrtisipasi dari masyarakat Indonesia untuk hidup sehat dengan mematuhi kebijakan yang telah dikeluarkan oleh pemerintah Indonesia. Kebijakan pemerintah yang tepat tanpa dukungan rakyat tentu hasilnya tidak berjalan optimal dan tidak akan mendukung terwujudnya kepentingan nasional.

Indonesia mengalami penurunan laju perekonomian sejak pandemi COVID-19 dan pemberlakuan PSBB di berbagai daerah di Indonesia. Berdasarkan laporan Bank Indonesia $(\mathrm{BI})$, pertumbuhan ekonomi Indonesia pada triwulan I tahun 2020 sebesar $2.97 \%$. Kemudian pada triwulan II tahun 2020, pertumbuhan ekonomi Indonesia sebesar minus 5,32\%. Hal ini juga disebabkan oleh melemahnya perekonomian global (Widjanarko 2020).

Berdasarkan penurunan laju pertumbuhan ekonomi Indonesia yang disebabkan oleh COVID-19, maka dapat diuraikan beberapa hal sebagai berikut:

a. Terjadinya fluktuasi Rupiah terhadap Dollar AS. Setiap kenaikan $1 \%$ kasus COVID-19 yang dilaporkan, menyebabkan 0,02\% depresiasi Rupiah terhadap Dollar AS dan menyebabkan 0,03\% koreksi ke IHSG. Peningkatan 1\% dari IHSG mengarah ke apresiasi Rupiah terhadap Dollar AS sebesar 0,311\%. Artinya pandemi COVID-19 berdampak terhadap fluktuasi nilai tukar Rupiah terhadap Dollar AS dan IHSG di Indonesia (Haryanto 2020).

b. Meningkatnya Tingkat Pengangguran Terbuka (TPT) di Indonesia. Berdasarkan data Bank Indonesia (BI), Pada bulan Agustus 2020 tingkat Pengangguran Terbuka (TPT) tercatat sebesar 7,07\% (yoy), sementara pada Agustus 2019 hanya sebesar 5,23\%. Berdasarkan laporan BI tersebut kenaikan tingkat pengangguran terjadi di wilayah perkotaan yang menerapkan protokol COVID-19 dengan lebih ketat (Bank Indonesia 2020b).

c. Terganggunya sistem pangan di Indonesia. Pada pertengahan bulan April persediaan pangan di Indonesia masih stabil dan tidak ada kekurangan, namun pada akhir bulan April beberapa provinsi di Indonesia melaporkan kekurangan beberapa persediaan makanan pokok, termasuk minyak goreng, telur (UNSDG 2020).

d. Kondisi penerbangan di Indonesia mengalami krisis karena banyak penerbangan yang dibatalkan. Sepanjang bulan Januari-Maret 2020, 12.703 penerbangan di 15 bandara di Indonesia dibatalkan, dimana dalam angka tersebut terdiri dari11.680 penerbangan domestik dan 1.023 penerbangan internasional. Hal ini berdampak pada hilangnya pendapatan pada pelayanan udara yang mencapai Rp 207 miliar. Krisis penerbangan ini juga berimbas kepada sektor pariwisata dan perhotelan di Indonesia, karena terjadi penurunan jumlah wisatawan hingga 6.800 perhari, khususnya wisatawan dari Tiongkok dan sebanyak 6 ribu hotel mengalami okupansi/penempatan penurunan pendapatan sebanyak $50 \%$. Penurunan pendapatan pada sektor perhotelan, diperkirakan berpotensi terhadap hilangnya devisa pariwisata yang mencapai setengah dari tahun lalu (Hanoatubun 2020). 
Selain kondisi perekonomian Indonesia yang terkena dampak dari penyebaran COVID-19, kondisi sosial di Indonesia juga perlu menjadi perhatian serius dari pemerintah Indonesia, diantaranya:

a. COVID-19 berdampak pada krisis sistem kesehatan di Indonesia. Cepatnya penyebaran COVID-19 ke berbagai provinsi yang ada di Indonesia menyebabkan tindakan pencegahan dan pengendalian infeksi (IPC) kurang memadai, berkurangnya ketersediaan dan suplai obat-obatan esensial, berkurangnya ketersedian tempat tidur dan tenaga kkesehatan terampil rumah sakit terutama di daerah tertinggal, mengganggu layanan kesehatan esensial seperti perawatan antenatal, persalinan yang aman, perawatan bayi baru lahir dan balita. Dampaknya juga dirasakan bagi masyarakat yang memiliki penyakit kronis atau penyakit yang memerlukan perawatan rutin dan tindak lanjut (UNSDG 2020).

b. COVID-19 berdampak pada terhambatnya fungsi-fungsi puskesmas termasuk para tenaga kesehatannya. Di Indonesia, lebih dari 6 persen kecamatan tidak memiliki puskesmas, dan banyak yang memang memiliki keterbatasan seperti listrik, air bersih dan peralatan yang memadai. Sekitar 21 persen puskesmas memiliki transportasi rujukan yang terbatas, dan 35 persen puskesmas telah membatasi penggunaan air bersih dan listrik dalam 24 jam (UNSDG 2020).

c. COVID-19 berdampak kepada sistem Pendidikan di Indonesia. Kebijakan yang dikeluarkan oleh Kementerian Pendidikan di Indonesia terkait pembelajaran daring (dalam jejaring) dengan meliburkan sekolah. ternyata menimbulkan permasalahan baru baik bagi siswa maupun bagi guru. Permasalahan yang muncul seperti kurangnya penguasaan teknologi informasi, sarana dan prasarana yang belum cukup memadai karena minimnya persiapan, serta akses Internet yang masih terbilang terbatas. Hal ini menyebabkan terjadinya kesenjangan antara peserta didik yang mampu dan tidak mampu (Martoredjo 2020).

\section{Strategi Politik Luar Negeri Indonesia Dalam Mitigasi COVID-19 melalui Alliance for Multilateralism}

Strategi politik politik luar negeri Indonesia dalam mitigasi pandemi COVID-19 adalah melalui Alliance for Multilateralism yang fokus pada dua hal, yaitu perlindungan terhadap WNI di luar negeri dan mendorong penguatan tata kekola dalam kerangka global health melalui kerangka kerjasama, baik regional maupun multilateral. Fokus pertama yaitu perlindungan dan penyelamatan $\mathrm{WNI}$, merupakan salah satu prioritas Kebijakan Politik Luar Negeri Indonesia 4+1. Adapun prioritas Kebijakan Politik Luar Negeri Indonesia 4+1 terdiri dari penguatan diplomasi ekonomi; diplomasi perlindungan; diplomasi kedaulatan dan kebangsaan; meningkatkan kontribusi dan kepemimpinan indonesia di kawasan dan dunia; dan memperkuat infrastruktur diplomasi (kemlu ri 2019).

Pada tanggal 23 januari 2020, kota Wuhan dikarantina oleh pemerintah Tiongkok, beberapa Warga Negara Indonesia (WNI) yang berada disana secara tidak langsung terancam keselamatannya dan tidak diperbolehkan keluar dari kota Wuhan. Menyikapi hal tersebut, pada tanggal 31 Januari 2020 kabinet diperintahkan oleh 
Presiden Jokowi untuk segera merepatriasi WNI yang berada di Wuhan, Provinsi Hubei, Tiongkok dengan beberapa prosedur mengingat COVID-19 sangat mudah penyebarannya melalui kontak fisik. Rencana pemulangan WNI dari Provinsi Hubei didukung oleh sejumlah pesawat yang disiagakan oleh TNI (Setiawan 2020). Upaya repatriasi ini merupakan bentuk perhatian khusus pemerintah Indonesia terhadap keselamatan WNI yang berada di luar negeri. Dalam skema repatriasi, prioritas utama pemerintah Indonesia adalah melindungi WNI, sehingga negara Indonesia hadir di mancanegara sebagai bentuk kebijakan dari pemerintah Indonesia dalam merespon penyebaran pandemi COVID-19.

Berdasarkan data Kementerian Luar Negeri pada bulan April hingga bulan Juli 2020, beberapa WNI telah kembali ke Indonesia, diantaranya ada yang melalui jalur udara, jalur laut dan jalur darat. WNI yang dipulangkan juga berasal dari berbagai negara. Sementara itu bagi WNI yang terkena kebijakan lockdown telah mendapatkan paket bantuan dari pemerintah Indonesia.

Pemerintah Indonesia menyadari semakin kompleksnya permasalahan yang muncul sebagai dampak dari penyebaran pandemi COVID-19 seperti dorongan migrasi yang semakin meningkat serta kemungkinan terjadinya kejatahan terorganisir lintas batas seperti Tindak Pidana Perdagangan Orang (TPPO). Mengingat dampak tersebut, melalui proses multilateral di PBB pemerintah Indonesia berupaya untuk menciptakan koridor agar migrasi berjalan aman dan adil bagi WNI maupun PMI (Pekerja Migran Indonesia) dengan disepakatinya Global Compact for Safe, Orderly and Regular Migration (GCM). GCM memiliki 4 tujuan, pertama perlunya data yang akurat. Untuk mendapatkan data WNI/PMI yang akurat dan terbaru, Kementerian Luar Negeri telah menggunakan pendekatan pelayanan publik 4.0 melalui dua platform digital yaitu Portal Peduli WNI dan Safe Travel. Kedua, penyediaan informasi yang akurat dan tepat waktu pada setiap tahapan migrasi. Ketiga, memfasilitasi pola rekrutmen yang adil dan etis. Keempat, mencegah, memberantas, dan menghapuskan perdagangan manusia (Kemlu RI 2020).

Kebijakan pemerintah dalam mitigasi pandemi COVID-19 tidak hanya terfokus pada upaya pemulangan WNI agar berjalan lancar dan adil, akan tetapi juga memberikan perhatian kepada WNI dinyatakan positif COVID-19. Berdasarkan data Kementerian Luar Negeri hingga akhir bulan Agustus, jumlah WNI yang terpapar COVID-19 sebanyak 24 ribu orang. Dari data tersebut, 1370 WNI dinyatakan meninggal. Pemerintah Indonesia dalam hal ini tetap memprioritaskan perlindungan kepada WNI dalam pelaksanaan politik luar negerinya. Pemerintah berupaya melakukan upaya pemantauan keselamatan WNI dengan memberikan pengobatan dan santunan terutama kepada WNI yang terkena kebijakan lockdown dan mengalami kesulitan hidup karena berkurangnya pendapatan. Pemerintah Indonesia telah memberikan paket bantuan bantuan kepada WNI yang terkena lockdown dengan total bantuan di seluruh dunia mencapai 5.22.086 paket. Dari angka tersebut, 451.098 paket bantuan diberikan kepada WNI yang berada di Malaysia (Setiawan 2020).

Pelaksanaan politik luar negeri Indonesia dalam mitigasi resiko pandemi COVID19 dengan memprioritaskan keselamatan WNI tentunya tidak terlepas dari berbagai kerjasama bilateral dengan berbagai negara maupun swasta serta melalui proses multilateral di PBB. Dengan adanya aplikasi digital Safe Travel, pemerintah Indonesia dapat memantau perkembangan data WNI di luar negeri, walaupun data diperoleh 
bukanlah data keseluruhan WNI karena beberapa diantara WNI tidak terdaftar secara legal. Proses pemulangan WNI juga bukan merupakan Langkah yang sederhana karena pemerintah maupun WNI harus mengikuti prosedur sesuai dengan protokol Kesehatan yang berlaku. Prosedur ini membutuhkan Kerjasama antar pemangku kepentingan terutama dalam setiap tahapan migrasi, yaitu sebelum, selama, dan sesudah penempatan atau dari hulu ke hilir.

Fokus kedua strategi politik luar negeri pemerintah Indonesia dalam mitigasi COVID-19 yaitu memperkuat tata kelola dalam kerangka Global Health. Global Health atau kesehatan global merupakan suatu konsep yang muncul dari proses perubahan politik da sejarah. Global health dapat didefinisikan atas lima kategori, yaitu jangkauan geografis, level kerja sama, target individu atau populasi, akses kesehatan, dan rentang disiplin ilmu. Berdasarkan jangkauan geografis, global health fokus pada isu-isu baik yang secara langsung maupun tidak langsung mempengaruhi kesehatan yang dapat melampaui batas nasional. Level kerjasama dalam kerangka global health adalah pengembangan dan penerapan solusi yang membutuhkan Kerjasama internasional. Target individu atau populasinya mencakup program pencegahan dalam populasi dan perawatan klinis individu. Tujuan utamanya adalah akses kesehatan yang dapat dijangkau oleh semua negara dan masyarakat dan riset terkait global health tidak hanya terkait ilmu Kesehatan melainkan meliputi meliputi multidisiplin ilmu (Kemlu RI 2018).

Pandemi COVID-19 yang terjadi sejak Desember 2019 hingga saat ini menunjukkan bahwa tata Kelola Kesehatan global masih lemah. Banyak negara yang mengambil kebijakan sendiri dari pada berkoordinasi dengan World Health Oraganization (WHO) dalam merespon krisis kesehatan global yang sedang terjadi saat ini, karena WHO dinilai tidak cepat tanggap dalam menyelasaikan pandemi. Namun beberapa negara lainnya tetap mendukung kebijakan WHO termasuk Indonesia. Indonesia berupaya untuk membangun kerjasama multilateral guna mendukung tata kelola kesehatan global dalam mitigasi resiko COVID-19.

Indonesia merupakan salah satu negara yang memprakarsai resolusi yang bertajuk "Global solidarity to fight the coronavirus disease 2019" pada tanggal 27 Maret 2020. Resolusi dengan nomor A/74/L.52 ini merupakan bentuk upaya guna membangun koordinasi global ketika negara-negara adi daya tidak ikut serta di dalamnya. Resolusi yang diprakarsai Indonesia ini fokus pada upaya kerjasama secara intens dalam mencegah dan mitigasi pandemi melalui sharing informasi, menyebarkan pengetahuan atas praktik-praktik terbaik, serta mendorong WHO menyiapkan sebuah panduan yang instruktif (Rum, dkk. 2020).

Indonesia dalam upaya mitigasi resiko pandemi COVID-19 juga terlihat dalam pertemuan $25^{\text {th }}$ Meeting of the ASEAN Coordinating Council (ACC) melalui video conference pada tanggal 9 April 2020. Menteri luar negeri yang hadir pada pertemuan ini menyepakati untuk meningkatkan upaya penanganan COVID-19. Menteri luar negeri Indonesia menggaris bawahi empat hal utama. Pertama, Indonesia menegaskan pentingnya implementasi hasil pertemuan Menteri Kesehatan ASEAN dan ASEAN Plus Three dan mengusulkan dalam Konferensi Tingkat Tinggi (KTT) ASEAN terkait pandemi COVID-19 agar para Pemimpin negara-negara anggota ASEAN dapat menginstruksikan mekanisme penyusunan protocol for cross-border public health responses. Kedua, Indonesia mengusulkan agar kebijakan Supply Chain and Flow of Goods during the Outbreak dibahas dalam KTT ASEAN Plus Three. Ketiga, Indonesia 
menekankan pentingnya peran ASEAN dalam melindungi warga negara baik kelompok rentan maupun pekerja migran sesuai dengan protokol kesehatan yang berlaku. Indonesia bahkan mengusulkan Langkah pemulihan pasca pandemi melalui protocol of movement of people within ASEAN Member States. Keempat, Indonesia mengusulkan agar negara anggota ASEAN memastikan ketersediaan peralatan medis dengan membentuk ASEAN COVID-19 Response Fund melalui ASEAN Development Fund dan APT Cooperation Fund (Kemenlu RI 2020).

Pada tanggal 14-16 April 2020 diadakan pertemuan Musim Semi IMF dan Bank Dunia yang diselenggarakan secara virtual dan dihadiri secara virtual oleh Gubernur Bank Sentral dan Menteri Keuangan dari berbagai negara. Dalam pertemuan ini, Indonesia mendorong implementasi respons bauran kebijakan yang terkoordinasi, untuk mitigasi dampak COVID-19 pada aspek ekonomi. Seluruh negara yang hadir termasuk Indonesia mendukung G20 Action Plan guna menghadapi krisis yang disebabkan oleh pandemi COVID-19 sebagai referensi respons kebijakan untuk mitigasi dampak wabah COVID-19 (Bank Indonesia 2020a). Belum ada satupun negara yang bisa memastikan kapan pandemi COVID-19 berakhir, sementara pertumbuhan ekonomi dunia mengalami kontraksi sehingga pentingnya merumuskan kebijakan luar negeri yang tepat dalam mitigasi resiko pandemi.

Indonesia juga merupakan bagian dari forum Foreign Policy and Global Health (FPGH) bersama dengan enam negara lainnya, yaitu Brazil, Perancis, Norwegia, Senegal, Afrika Selatan dan Thailand. Pada bulan Maret 2007 sebelumnya, telah disepakati Oslo Ministerial Declaration dalam pertemuan Menteri luar negeri FPGH di Oslo, Norwegia. Deklarasi tersebut menegaskan tujuan FPGH untuk membangun sinergi antara kebijakan politik luar negeri dengan global health pada berbagai forum bilateral, regional dan multilateral (Widyawati 2021).

Pada tanggal 18 Mei 2020, para Menteri Kesehatan FPGH melakukan Virtual Meeting yang dipimpin Menteri Kesehatan Republik Indonesia dan menghasilkan Joint Statement yang terdiri dari 2 tema, antara lain kerjasama dalam penanganan COVID-19 dan affordable health care for all yang memuat komitmen negara-negara FPGH untuk meningkatkan solidaritas dan kerja sama internasional dalam kesiapsiagaan dan mitigasi pandemi COVID-19 serta memperkuat sistem kesehatan yang berfokus pada pelayanan kesehatan primer. Virtual Meeting juga menekankan perlunya kegiatan serupa untuk menjamin tersedianya layanan kesehatan yang dapat dijangkau oleh semua orang dalam rangka pencapaian Universal Health Coverage (UHC) serta sasaran Sustainable Development Goals (SDGs) pada tahun 2030 (Widyawati 2021).

Indonesia juga berpartisipasi dalam Solidarity Trial yang bertujuan untuk menemukan vaksin yang tepat bagi penanganan COVID-19. Pada tanggal 19-21 Agustus 2020, pemerintah yang diwakilkan oleh Menteri Luar Negeri Republik Indonesia dan Menteri Badan Usaha Milik Negara (BUMN) melakukan kunjungan ke Tiongkok dan Uni Emirat Arab (UEA) dalam rangka kerjasama pengembangan vaksin COVID-19. Dalam rangka kerjasama pengembangan vaksin COVID-19 oleh beberpa perusahaan seperti G-42, UEA dengan Sinopharm, Tiongkok dan Kimia Farma, UEA berkomitmen untuk menyediakan 10 juta vaksin bagi Indonesia (BPOM RI 2020).

Pada tanggal 24-26 Agustus 2020, Kepala BPOM Republik Indonesia melakukan kunjungan kerja ke Uni Emirat Arab (UEA) dan melakukan pertemuan dengan Amin Hussain Al Amiri dari Kementerian Kesehatan UEA, Jamal Alkaabi dari Kementerian 
Kesehatan Abu Dhabi dan Mr. Peng Xiao yang merupakan CEO Group-42 (G-42), Sinopharm serta mengunjungi Vaccine Testing Centre yang berlokasi di Abu Dhabi National Exhibition Centre. Kerjasama ini memberikan peluang bagi Indonesia untuk memperoleh vaksin sesuai kebutuhan Indonsia dan mengembangkan industri farmasi dengan mengekspor obat-obatan dan vaksin dari Indonesia ke negara-negara Timur Tengah serta mendorong implementasi Rencana Aksi OKI dalam mendukung kemandirian obat dan vaksin di negara anggota OKI (BPOM RI 2020).

Secara keseluruhan serangkaian kerjasama internasional yang dijalin oleh pemerintah Indonesia adalah sebagai bentuk dukungan pemerintah Indonesia dalam memperkuat tata kelola dalam kerangkan global health. Negara-negara di dunia termasuk Indonesia tidak lagi hanya mengharapkan kapasitas WHO untuk menyelesaikan pandemi karena pandemi yang terjadi saat ini berbeda dari pernah terjadi sebelumnya. Oleh karena itu dibutuhkan kerjasama berbagai negara di dunia untuk mencegah penyebarannya dan menemukan vaksin yang tepat agar dapat digunakan oleh masyarakat internasional.

\section{Faktor-Faktor yang Mempengaruhi Strategi Politik Luar Negeri Indonesia dalam Mitigasi COVID-19}

Setiap negara telah mengambil berbagai kebijakan dalam menghadapi pandemi COVID-19. Pandemi ini bahkan telah menyatukan kepentingan negara-negara di seluruh dunia yang terkena dampaknya. Hal ini tentunya tidak terlepas dari strategi politik luar negeri pada masing-masing negara termasuk Indonesia. Dalam menganalisis strategi politik luar negeri Indonesia dalam mitigasi COVID-19 dapat ditinjau dari dua aspek. Pertama, kepentingan nasional Indonesia yang mengedepankan diplomasi pro rakyat. Artinya pemerintah Indonesia tetap mengutamakan kepentingan rakyat dalam pelaksanaan politik luar negerinya. Situasi pandemi COVID-19 menyebabkan beberapa negara menjadi saling tuduh dan saling curiga hingga melakukan propaganda terkait asal virus dan meragukan kinerja dari WHO sebagai sebuah organisasi internasional yang mengatur tata Kelola Kesehatan global. Sementara itu dari pada terlibat di dalam konflik, pemerintah Indonesia mengambil suatu kebijakan perlindungan terhadap warga negara Indonesia baik yang ada di dalam negeri maupun yang ada di luar negeri.

Sejak bulan Maret 2020, pemerintah telah melakukan upaya penyelamatan bagi WNI baik yang berada di Wuhan maupun di negara-negara lainnya. Dalam upaya penyelamatan $\mathrm{WNI}$ yang berada di Amerika Serikat, Pemerintah Indonesia melalui Perwakilan Tetap Republik Indonesia (PTRI) untuk PBB di New York memprioritaskan perlindungan WNI dengan cara melakukan koordinasi untuk merespon dan mengurangi meluasnya dampak pandemi di Amerika Serikat. Selain itu, enam perwaklian Indonesia di Amerika Serikat yang terdiri dari Keduataan Besar Republik Indonesia (KBRI) di Washington DC, Konsulat Jenderal Republik Indonesia (KJRI) New York, KJRI Los Angeles, KJRI Chicago, KJRI San Francisco, dan KJRI Houston ikut serta dalam upaya perlindungan dan penyelamatan WNI di Amerika Serikat (Setiawan 2020).

Indonesia juga menekankan pentingnya kerjasama bilateral guna menekan jumlah warga Indonesia yang positif COVID-19. Indonesia bekerjasama dengan Korea Selatan, karena merupakan salah satu negara di Asia yang berhasil menekan kurva 
jumlah warga yang positif COVID-19. Upaya yang dilakukan oleh pemerintah Korea Selatan adalah melakukan rapid test besar-besaran yang agar pemerintah dapat dengan mudah melacak dan merespon cepat terhadap penyebaran COVID-19. Selain itu juga adanya dukungan dari perusahaan bioteknologi Korea Selatan, Kogene Biotech dan Seegene dalam menyediakan peralatan tes (testing kits) COVID-19. Melalui kerjasama bilateral ini, Pemerintah Korea Selatan akan memberi bantuan Indonesia senilai US $\$ 500$ ribu kepada Pemerintah untuk mendukung upaya mitigasi penyebaran COVID-19 di Indonesia. Bantuan tersebut terdiri dari COVID-19 test kits dan rechargeable battery power sprayers. Pihak swasta dari Korea Selatan seperti LG Group juga akan memberikan bantuan kepada pemerintah Indonesia sebanyak 50 ribu COVID-19 diagnostic kit (tipe RTPCR), dan Hyundai Motor memberikan bantuan sebanyak 40 ribu APD (Berita Indonesia 2020).

Setiap koordinasi yang dilakukan oleh perwakilan Indonesia di luar negeri sejalan dengan kebijakan yang dipilih oleh pemerintah Indonesia. Politik luar negeri Indonesia yang difokuskan pada upaya perlindungan warga negara Indonesia sebenarnya tidak terlepas dari tujuan politik luar negeri Indonesia yaitu untuk meraih kesejahteraan maysarakat Indonesia. Melalui instrumen diplomasi perlindungan, pemerintah Indonesia gencar melakukan kerjasama dalam menemukan vaksin baik dalam kerangka bilateral maupun multilateral agar pandemi yang menimbulkan kepanikan dan mengancam keamanan manusia di Indonesia segera dapat diatasi.

Aspek kedua yang mempengaruhi strategi politik luar negeri Indonesia dalam mitigasi COVID-19 adalah konstelasi politik internasional yang ditunjukkan dengan kondisi hubungan internasional yang penuh akan polemik. Hal ini dikaitkan dengan adanya keterlibatan dari negara-negara maju yang terlibat persaingan dagang dalam bidang industri kesehatan seperti Amerika Serikat dan Tiongkok. Amerika Serikat yang sebelumnya telah menyepakati perjanjian dagang fase I Tiongkok, mengapresiasi Tiongkok dalam menangani COVID-19 pada awal tahun 2020. Namun Ketika COVID19 mulai menyebar dengan cepat ke berbagai negara termasuk Amerika Serikat dan belum ditemukannya vaksin yang tepat, Pemerintah Amerika Serikat mulai mengeluarkan kebijakan penangguhan kepada orang-orang dengan riwayat perjalanan dari Tiongkok yang berencana masuk ke Amerika Serikat (Akhli 2020).

Pemerintah Amerika Serikat menyebutkan bahwa pandemi COVID-19 sebagai "Chinese Virus" atau "Wuhan Virus". Label diberikan berdasarkan tempat dimana virus tersebut ditemukan. Hal ini kemudian ditentang oleh WHO karena label tersebut mengandung stigmatisasi rasial. Pemerintah Amerika Serikat tidak menghiraukan larangan WHO dan mengklaim bahwa Sekretaris Jenderal WHO, Dr. Tedros sebagai kaki tangan Tiongkok. WHO dinilai lambat dalam menangani pandemi COVID-19 (Akhli 2020).

Sikap pemerintah Amerika Serikat mendapat respon dari pemerintah Tiongkok. Berbagai tuduhan yang ditujukan kepada pemerintah Tiongkok tidak mempengaruhi ambisius Tingkok dalam melaksanakan politik luar negerinya. Di saat negara Uni Eropa dan Amerika Serikat menunjukkan ketidaksiapanya dalam menghadapi pandemi COVID-19, Tiongkok melakukan diplomasi di beberapa negara melalui bantuanbantuan medis. Tiongkok bahkan mengklaim bahwa Amerika Serikat ingin memulai perang dingin dengan membawa isu COVID-19 yang mungkin saja berasal dari militer Amerika Serikat yang dibawa ke Wuhan (Akhli 2020). 
Konstelasi politik internasional kemudian menjadi semakin konfliktual ketika pemerintah Amerika Serikat menghentikan pendanaannya untuk WHO yang bernilai sekitar 500 juta dolar Amerika atau 7.8 triliun rupiah per tahun dan berencana keluar dari keanggotaan WHO (Sushanti 2020). Namun momen ini dimanfaatkan oleh Tiongkok dengan semakin memperlihatkan perannya di dalam WHO. Pemerintah Tiongkok memberikan anggaran sebanyak 30 juta Dolar kepada WHO dalam upaya mitigasi risiko pandemi COVID-19 (Akhli 2020).

Konstelasi politik internasional merupakan salah satu pertimbangan pemerintah Indonesia dalam upaya mitigasi resiko pandemi COVID-19. Indonesia dengan prinsip politik luar negerinya "Bebas dan Aktif" tidak ikut terlibat dalam perseteruan dua negara adi daya tersebut. Pemerintah Indonesia lebih cenderung fokus pada politik domestiknya dibandingkan memperjuangkan kepentingan negara lain. Sebagai bagian dari masyarakat internasional, pemerintah Indonesia menunjukkan solidaritasnya dalam mitigasi resiko COVID-19 dengan menjalin kerjasama baik secara bilateral maupun multilateral. Pemerintah Indonesia berupaya agar kebijakan luar negeri Indonesia bisa adaptif dalam kondisi pandemi COVID-19 melalui diplomasi perlindungan. Diplomasi perlindungan yang dilakukan oleh pemerintah Indonesia mempriotaskan keselamatan dan perlindungan bagi WNI dan PMI yang tersebar diseluruh dunia. Pemerintah Indonesia lebih berupaya menghadirkan negara dalam masyarakat dari pada terlibat dalam aksi propaganda negara-negara yang memanfaatkan kondisi pandemi COVID-19 dalam perpolitikan internasional.

\section{KESIMPULAN}

Strategi politik luar negeri Indonesia merupakan suatu perwujudan sebagaimana yang diamanatkan dalam pembukaan UUD 1945 yaitu ikut melaksanakan perdamaian dunia. Artinya melalui kerangka multilateralisme, pemerintah Indonesia menyadari bahwa pandemi COVID-19 bukan lagi terkait permasalahan keamanan nasional suatu negara melainkan ancaman terhadap keamanan manusia di seluruh dunia. Pemerintah Indonesia berupaya mengajak negara-negara di dunia melalui Alliance of Multilateralism untuk saling bekerja sama dalam hal penanganan pandemi, mulai dari memberikan bantuan berupa peralatan medis yang esensial, alat pelindung diri, obatobatan dan vaksin bagi negara-negara yang membutuhkan, hingga upaya untuk memfasilitasi pergerakan dan alur barang agar dapat terus menopang perdagangan dan rantai pasokan global selama masa pandemi COVID-19 berlangsung.

Pandemi COVID-19 merupakan krisis kesehatan global, sehingga juga butuh penanganan bersama dari masyarakat internasional. Kondisi perekonomian dunia yang semakin memburuk serta tingginya angka kematian yang disebabkan oleh pandemi menujukkan bahwa mitigasi adalah suatu langkah tepat yang dilakukan oleh masyarakat internasional dari pada propaganda politik untuk saling tuduh terkait asal muasal COVID-19. Artinya masyarakat internasional tidak memiliki opsi lain selain menyesuaikan serangkaian kebijakan yang dibuat oleh WHO untuk diterapkan di negara masing-masing serta memanfaatkan WHO sebagai wadah kerjasama bagi seluruh negara anggota PBB. 


\section{REFERENSI}

Akhli, Rangga Amalul. 2020. "Kepentingan Politik Donald Trump Dan Xi Jinping Dalam Meningkatkan Relasi Konfliktual Antara AS-Tiongkok Di Masa Pandemi Covid-19." Jurnal Penelitian Politik 17(2).

Alliance for Multilateralism. "What is the „Alliance for Multilateralism"?" https://multilateralism.org/the-alliance/https:/multilateralism.org/the-alliance/ (July 31, 2021).

Bank Indonesia. 2020a. "Indonesia Dorong Kerjasama Internasional Mengatasi Dampak Pandemi COVID-19." https://www.bi.go.id/id/publikasi/ruang-media/newsrelease/Pages/sp_223220.aspx (December 22, 2020).

- 2020b. "Laporan Kebijakan Moneter Triwulan III 2020." https://www.bi.go.id/id/publikasi/kebijakanmoneter/tinjauan/Pages/LaporanKebijakan-Moneter-Triwulan-III-2020.aspx (December 19, 2020).

Berita Indonesia. 2020. "Indonesia Perkuat Kerja Sama Bilateral Dengan Korsel Dalam Penanganan Pandemi Covid-19." http:///Downloads/berita-indonesia-perkuat-kerjasama-bilateral-dengan-korsel-dalam-penanganan-pandemi-covid-19_2021-03-24 19_12_17.pdf (December 15, 2020).

BPOM RI. 2020. "Dukung Percepatan Kerja Sama Vaksin Covid-19, Badan Pom Lakukan Kerja Sama Dengan Uni Emirat Arab." https://pom.go.id/new/view/more/pers/561/DUKUNG-PERCEPATAN-KERJASAMA-VAKSIN-COVID-19 (December 8, 2020).

Financial Times. 2020. "China to Give WHO an Extra \$30m to Fight Coronavirus."

Hanoatubun, Silpa. 2020. "Dampak Covid-19 Terhadap Perekonomian Indonesia." EduPsyCouns Journal: Journal of Education, Psychology and Counselling 2(1): 146-53.

Hanrieder, Wolfram, F. 1971. Comparative Foreign Policy: Theoretical Essays. New York: David McKay Co.

Haryanto. 2020. "Dampak Covid-19 Terhadap Pergerakan Nilai Tukar Rupiah Dan Indeks Harga Saham Gabungan (IHSG)." The Indonesian Journal of Development Planning 4(2): 151-65.

Kemenlu RI. 2020. "Mesin Diplomasi ASEAN Terus Bekerja Hadapi COVID-19." https://kemlu.go.id/portal/id/read/1188/berita/mesin-diplomasi-asean-terus-bekerjahadapi-covid-19 (December 22, 2020).

Kemlu RI. 2018. Kesehatan Untuk Semua: Strategi Diplomasi Kesehatan Global Indonesia. Jakarta: BPPK.

- 2019. "Penyampaian Prioritas Politik Luar Negeri Republik Indonesia 20192024." https://kemlu.go.id/portal/id/read/725/pidato/penyampaian-prioritas-politikluar-negeri-republik-indonesia-2019-2024 (December 10, 2020).

_ . 2020. "Sinergita Tata Kelola Penempatan, Dan Perlindungan Pekerja Migran." https://kemlu.go.id/portal/id/read/1903/view/sinergitas-tata-kelola-penempatan-danpelindungan-pekerja-migran.

Martoredjo, N. Thomas. 2020. "Pandemi COVID-19: Ancaman Atau Tantangan Bagi Sektor Pendidikan?" https://core.ac.uk/download/pdf/328807842.pdf (December 20, 2020).

Mas'oed, Mochtar. 1990. Ilmu Hubungan Internasional: Disiplin Dan Metodologi. Jakarta: LP3ES. 
OCHA, and CRO. 2020. "Indonesia Multi-Sectoral Response Plan to COVID-19." https://unsdg.un.org/resources/indonesia-multi-sectoral-response-plan-covid-19 (December 19, 2020).

Perwinta, A.A. Banyu. 2007. "Agenda Dan Tantangan Politik Luar Negri." Global 9(9).

Perwinta, A.A. Banyu, and Y.M. Yani. 2005. Pengantar Ilmu Hubungan Internasional. Bandung: PT Remaja Rosdakarya.

Plano, J. C., and R. Olton. 1982. The International Dictionary. Third Edit. England: Clio Press Ltd.

Rum, Muhammad, dkk. 2020. "Keterbatasan Tata Kelola Kesehatan Global Dalam Penanganan COVID-19." https://www.researchgate.net/publication/341232836 (December 12, 2020).

Sabir, M. 1987. Politik Bebas Aktif. Jakarta: Cv. Hj Masaung.

Setiawan, Asep. 2020. "Politik Luar Negeri Indonesia Era Covid-19: Penyelamatan Dan Kerjasama." Independen: Jurnal Politik Indonesia dan Global 1(2).

Sugiyono. 2012. Metode Penelitian Kuantitatif, Kualitatif Dan R\&D. Bandung: Alfabeta.

Sushanti, Sukma. 2020. "Kontestasi Negara Di Tengah Pandemi COVID-19.” Jurnal IImiah Sosiapolitika 2(1): 14-23.

U.S. Embassy Jakarta. 2020. "Pembaruan Informasi: Amerika Serikat Terus Memimpin Respons Global Terhadap COVID-19." https://id.usembassy.gov/id/pembaruaninformasi-amerika-serikat-terus-memimpin-respons-global-terhadap-covid-19-2/ (November 18, 2020).

UNSDG. 2020. "Indonesia Multi-Sectoral Response Plan to COVID-19." https://unsdg.un.org/resources/indonesia-multi-sectoral-response-plan-covid-19 (December 19, 2020).

Widjanarko, Onny. 2020. "Covid-19 Tekan Pertumbuhan Ekonomi Indonesia Triwulan II 2020.” https://www.bi.go.id/id/ruang-media/siaranpers/Pages/sp_225520.aspx (December 19, 2020).

Widyawati. 2021. "Indonesia Pimpin Foreign Policy and Global Health Dukung Upaya Global Akhiri Pandemi COVID-19." https://sehatnegeriku.kemkes.go.id/baca/umum/20200518/3033922/indonesiapimpin-foreign-policy-and-global-health-dukung-upaya-global-akhiri-pandemi-covid19/ (January 28, 2021). 